\title{
International Competitive Strategy Choices: Comparing Firms in China and India
}

Ping Lv

Monica Plechero

Rakesh Basant

Xie-Lin Liu

W.P. No. 2012-01-05

January 2012

The main objective of the working paper series of the IIMA is to help faculty members, research staff and doctoral students to speedily share their research findings with professional colleagues and test their research findings at the pre-publication stage. IIMA is committed to maintain academic freedom. The opinion(s), view(s) and conclusion(s) expressed in the working paper are those of the authors and not that of IIMA.

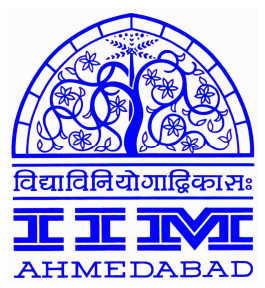




\title{
International Competitive Strategy Choices: Comparing Firms in China and India
}

\author{
Ping Lv \\ Graduate University of Chinese Academy of Sciences, School of Management, No.80, \\ Zhongguancun East Road, Beijing 100190, China. (1vping@gucas.ac.cn) \\ Monica Plechero \\ Lund University, CIRCLE, Sölvegatan 16, S-221 00 Lund, Sweden. Italian National \\ Research Council, IRPPS, Via Palestro 32, 00185 Rome, Italy. \\ (monica.plechero@,circle.lu.se) \\ Rakesh Basant \\ Indian Institute of Management, Vastrapur, Ahmedabad, India \\ (rakesh@iimahd.ernet.in)

\section{Xie-Lin Liu} \\ Graduate University of Chinese Academy of Sciences, School of Management, No.80, \\ Zhongguancun East Road, Beijing 100190, China. (liuxielin@gucas.ac.cn)
}

The authors acknowledge and are grateful for the cooperation and financial support provided by Swedish Research Council. Comments by Ziqi Liao, Hong Kong Baptist University, and Gary H Jefferson, Brandeis University, were helpful in revising this paper. The authors alone are responsible for all limitations and errors that may relate to the study and the paper. 


\title{
International Competitive Strategy Choices: Comparing Firms in China and India
}

\begin{abstract}
The international business literature has yet to adequately explore international competitive strategy choices made by firms in developing countries. This study aims to address this gap by investigating the types of international competitive strategies followed by Chinese and Indian firms. Using firm-level primary data, the study analyzes factors that affect strategy choices and whether these factors differ between the two countries. The empirical results indicate that besides cost leadership strategies, firms have already developed international differentiation strategies and strategies combining cost and differentiation advantages (hybrid strategies). This confirms that firms from China and India are moving to international markets not only because of their low cost advantage but also because they are upgrading their capabilities to compete in the global market. The study highlights the fact that firms' resources and capabilities influence firms' propensity to choose a specific international competitive strategy and that the strategies can also differ in relation to the destination market. In general, the pursuit of well-articulated international competitive strategies (in particular differentiation strategy) is more common among Indian firms than among Chinese firms.
\end{abstract}

Keywords: international competitive strategy; China; India; resources; capabilities 


\section{Introduction}

Internationalization, i.e. the different types of involvement of firms (export, FDI) in international markets, is increasingly becoming an important research field in business economics. The ongoing globalization processes, information and communication technologies (ICT) development and more active participation of firms from developing countries in the worldwide economic competition is contributing to increase the phenomenon. For this reason, research on international competitive strategy (ICS), as a sub-discipline of global strategy, is gaining interest among scholars (Peng, 2005).

Until now, research in the area of ICS has focused mainly on issues relating to the taxonomy of business-level strategies (Morrison and Roth, 1992), the performance implications of strategic choices (Dominguez and Sequeira, 1993), business-level strategy formulation (Collis, 1991) and its implementation (Roth et al., 1991). Although the investigation of factors that affect the internationalization processes is considered to be a very important issue (Wang et al., 2008), most studies ignore the possible antecedents that affect ICS choices. Moreover, little is known about firms' ICS choices in emerging economies. Countries like China or India, with their increasing participation in global production and innovation networks (Altenburg et al., 2008; OECD, 2008), are threatening the competitive capacities and stability of firms from developed countries.

Despite the economic growth of India and China and their recognized international competitive position, many researchers still argue that the competitive strengths of China and India are based on cost advantage in terms of labor especially driven by the easy availability of highly-skilled laborers (Kostoff et al., 2007; Saran and Guo, 2005). Consequently, an examination of the nature of competitive strategies (cost-based, differentiation or hybrid) undertaken by firms in these two countries while considering their antecedents would be useful. 
This paper aims to contribute to global strategy studies in four ways. Firstly, it explores strategic choices in the context of internationalization for firms located in developing countries rather than focusing on firms in developed countries and their domestic markets, as most existing studies do. Secondly, it uses the resource-based view (RBV) to analyze the impact of firms' resources and capabilities on such strategic choices. Thirdly, while analyzing these strategies, it distinguishes between less developed country markets (LDCM) and developed country markets (DCM). Fourthly, it explores differences in patterns of internationalization between China and India.

The remainder of the paper is organized as follows. Section 2 provides details of the theoretical framework and hypotheses. The data and the methodology used in the empirical analysis are discussed in Section 3. Section 4 presents the results of the empirical analysis. The final section discusses the results and summarizes the key findings.

\section{Theory and hypotheses}

\subsection{Competitive strategies in an international context}

In the competitive strategy framework, a successful business is one which sustains an attractive relative position for the firm. Porter $(1980,1985,1991)$ suggests two generic, but fundamentally different approaches to creating and sustaining a competitive advantage: cost strategy and differentiation strategy. Besides, Porter's thesis of "stuck in the middle" (Porter, 1980, 1996) argues that these two strategies cannot be combined. While a firm focusing on cost leadership has to maintain a certain standard for its products, reducing the possibility to create economies of scope, a firm focusing on differentiation may find it difficult to maintain low costs and compete with other firms that produce more standardized products for the same market.

After Porter's seminal work, some recent studies have moved away from the thesis that the two strategies can not be combined. Many suggest that a combination of cost leadership and differentiation is not only a feasible option (e.g. Hill, 1988; Miller and 
Friesen, 1986a, 1986b), but also a successful approach to improve competitive position and to cope with rapid and complex changes in the market environment (Acquaah and Yasai-Ardekani, 2008; Gopalakrishna and Subramanian, 2001; Pertusa-Ortega et al., 2009). The adoption of a hybrid strategy as opposed to a pure strategy may (i) better address customer needs in a more appropriate way; (ii) be more difficult to be imitated by competitors; and (iii) generate a more flexible way to operate in the market (Miller, 1992). Typically, existing studies examine competitive strategies in domestic markets. However, for firms seeking benefits from foreign markets, the type of competitive strategies they choose may represent an important vehicle by which they build a distinctive business position at the international level and achieve superior financial returns (Allred and Swan, 2004; Luo and Zhao, 2004).

\subsection{International competitive strategies in developing countries}

The evidence relating to the type of ICS present in the literature are limited to databases or cases from developed countries. Nevertheless, internationalization of firms from developing countries, in particular from China and India, has increased significantly in the last decade (OECD, 2008). According to Hymer (1976) and Dunning's $(1980,1988)$ eclectic OLI framework, one pre-requisite for firms' international expansion is that they must possess unique advantages such as superior assets and skills. In general, firms from developing countries have relatively lower technological and knowledge-based advantages than firms from developed countries. This means that the ability to differentiate from competitors and to maintain a flexible approach to strategizing may be lower for the former set of nations. Given limited capabilities at the firm level and lack of institutional support, firms in these countries remain (when not imitators) mainly adapters or incremental innovators, far from the frontier of technological advancement and type of products, processes and organizational innovations present in developed countries (Altenburg et al., 2008; Srholec, 2008). Accordingly, with this framework, firms from emerging economies would depend more on cost advantage rather than differentiation or hybrid strategies in international competition. 
Among developing countries, China and India are playing an important role at the world stage, not only as emerging economies being able to attract foreign direct investments (UNCTAD, 2005), but also as countries that are increasing their presence in the international marketplace. The outflow of FDI from China and India has increased by $57 \%$ and 35\%, respectively, between 2000 and 2008 (UNCTAD, 2009). In addition, the export of products and services to other countries is rising very rapidly. China and India's exports accounted for $8.9 \%$ and $1.1 \%$ of the world's total exports in 2008.

While many developing countries generate very few indigenous innovations, both China and India seem to be climbing up in the innovation space in the global environment (Zhao and Watanabe, 2008). China, with its independent innovation policy, is experiencing the transition from a "catching-up" country to an "innovation-driven" country ( $\mathrm{Mu}$ and $\mathrm{Qu}, 2008)$, while India is playing the role of "interdependent innovator", serving multinational companies and developing technologies for global markets (Segal, 2008). The recent trends in R\&D expenditure and R\&D FDI show the increasing innovation commitment and attraction of these two countries. Since 1999, China's expenditure on R\&D has increased by more than $20 \%$ per year and, in 2005, expenditure reached $1.3 \%$ of the country's gross domestic product in that year (Wilsdon and Keeley, 2007). The R\&D expenditure in India has not grown at such impressive rates in recent years and constitutes around $0.8 \%$ of GDP today, but the share of R\&D undertaken by the private sector has risen rapidly (Mani, 2009).

China and India are therefore among the emerging economies that are at the frontier of building up innovation capabilities (Altenburg et al., 2008; Bhattacharya and Nath, 2002). This is particularly true for certain regions within these two countries. For instance, Bangalore, Pune, Hyderabad, and Mumbai in India, and Beijing, Shanghai, Guangzhou, and Nanjing in China are emerging as locations with a large talent pool and substantial investments in innovation (Chaminade and Vang, 2008; Huggins et al., 2007). These regions are involved in the internationalization processes, not only 
in terms of exports but also in terms of inflow/outflow of FDI, and participation in global production and technology networks. Consequently, one can argue that competitive advantages of firms from these two countries and, in particular, from regions that have been technologically active, may have transitioned from cost leadership to differentiation or hybrid strategies.

2.3. The effect of firms' resources and capabilities on their international competitive strategies

The RBV provides a theoretical framework for how organizations develop a sustainable competitive advantage based on their unique resource endowments (Barney, 1991; Wernerfelt, 1984). As one of the dominant perspectives in literature on strategy, the RBV receives relatively little attention in the international business field (Bruton et al., 2004; Fahy, 2002). Only a few studies (e.g. Mascarenhas et al., 1998; Saarenketo et al., 2004) consider and analyze the influence of firm resources on processes of internationalization, but not on ICS. Indeed, firms with rare, valuable, inimitable and non-substitutable resources tend to compete in international markets in search of greater profitability (Peteraf, 1993). The RBV maintains that a firm would select a strategy that best exploits its resources and capabilities relative to external opportunities (Grant, 1991). This view offers a systematic framework for assessing the relative importance of the broad resources available to firms competing in a global environment (Fahy, 2002). One may argue that the more resources and competences a firm has, the greater will be its ability to develop a strategy to achieve competitive advantage (Ortega, 2009) in the international market. In this paper, we explore whether three major resources and capabilities relate to the adoption of ICS: human resources, technological resources and organizational capabilities.

Human resources. In the RBV, it is frequently argued that human capital contributes to a firm's competitive advantage due to inimitability based on its intangible, firm-specific, and socially complex nature (Hatch and Dyer, 2004). In particular, human resources associated with individuals with differentiated skills, education, experience and training are likely to be productive resources for the firms (Hitt et al., 
2001). High quality human resources may affect the firm's competitive strategy, since they contribute to innovation and have a high absorptive capacity to use, acquire and develop strategic knowledge (Cohen and Levinthal, 1990; Simonen and McCann, 2008). A firm may use its pool of qualified talent for the development of differentiation or hybrid strategies as opposed to strategies based only on cost advantage. Since the level of education is a good proxy for the quality of human resources, we may expect that:

Hypothesis 1. Firms with a high percentage of qualified human resources are more likely to pursue differentiation or hybrid strategies (as compared to cost-based ones) to access international markets.

Technological resources. The level of technological resources is often associated with product innovation in global markets (Prasad et al., 2001). Generally, firms with advanced technological resources are more likely to produce high quality products or services, or launch differentiated products or services. In other words, as the level of firms' technological resources increases, their propensity to pursue a differentiation or hybrid strategy also increases. In terms of technological resources, we refer both to resources connected to technological capacity (firm's endowment of machinery and equipment compared with the average level of the industry) and resources linked to technological investment in innovation (R\&D investment). A firm's significant commitment to R\&D investment is a reflection of strategic importance that organization places on innovation activity. Even though some firms may outsource their production and manufacturing activities in intensely competitive international environments, firms need also to invest in in-house $R \& D$ in order to develop absorptive capacity and unique advantages (Blonigen and Taylor, 2000). The firm that invests in $R \& D$ is likely to compete on the basis of innovation and technology breakthrough (O’Brien, 2003), and expand rapidly into international markets (Lin et al., 2006). In particular, accumulated $R \& D$ is likely to contribute extensively to the development of new products for both domestic and international markets. Alternatively, if the R\&D and other investment in the firm are primarily geared 
towards process innovations, it may contribute also to a cost-based strategy for internationalization. In summary, we hypothesize that:

Hypothesis 2. Firms with advanced technological resources (more sophisticated machinery and equipment and $R \& D$ investments) are likely to pursue differentiation or hybrid strategies to access international markets.

Organizational capabilities. The successful implementation of a cost leadership strategy requires excellent value chain management that results in cost minimization within all development and manufacturing activities (Porter, 1985). It is well known in the business literature that value chain management can benefit from an application of complex in-house organizational techniques, such as quality control systems, just-in-time, and continuous improvement. The purpose of internal use of complex organizational techniques - which we can define as organizational capabilities - is to develop the capacity to be flexible in the market. Indeed, some scholars identify best practices of quality management, such as a good organization of systems of production, as a way to guide the firms to achieve both cost advantage and innovation. For example, Prajogo and Sohal (2006) show that there is a strong and positive correlation also between quality management of organization and innovation, while Tidd et al (1997) argue that quality management plays an important role in companies which compete aggressively using a differentiation strategy. As a part of organizational capabilities, the use of quality certification in a firm can be viewed as a way to implement quality management practices and sustain the firm in its production efficiency as well as innovation processes. We suggest the following hypothesis:

Hypothesis 3. Firms with a high level of organizational capabilities are likely to pursue a hybrid strategy (both cost leadership and differentiation strategy) to access international markets.

\section{Methodology}

\subsection{Data}

The empirical analysis to test the hypotheses is based on firm-level primary data 
collected through a survey in Pune (India) and Jing-Jin-Ji (China) (that includes Beijing, Tianjin and Hebei provinces) regions in 2008 and related to the year 2007. The two aforementioned areas represent important clusters and knowledge hubs in their respective countries. Moreover, the firms located there have considerable presence in international markets both in terms of FDI and export activities (Basant and Chandra, 2007; China Knowledge, 2010; Guan et al., 2009; MCCIA, 2008). The survey covered firms in three specific industrial sectors (automotive component, software and green-biotech) and focused on four main themes: innovation activities, internationalization strategies, competences and linkages. Lists of firms were generated for each sector and a random sample of firms was selected for the survey. In both countries the list of firms was compiled from different well recognized sources of data capturing firms of all sizes. The survey in China was supervised by GUCAS (Graduate University of Chinese Academy of Sciences), which used the data bases of a market research company (Sinotrust) and of a software testing center (CSTC). The Indian Institute of Management in Ahmedabad supervised the survey in India using databases bought from Indian industry associations. However, since the complete lists of firms in different sectors in the two clusters do not exist nor do we have information on the overall distribution of firms by size, we cannot evaluate possible biases due to differential response rates across size groups.

In China the survey was conducted mainly by phone with an average response rate of 20\%. The firms listed in the CSTC database were contacted by email and the response rate was about $7 \%$. The interviewee, as in India, was mainly the owner or top-level management of the firms. In India, the survey, with an average response rate of $40 \%$, was conducted using face to face interviews, followed up by phone calls when necessary. Since the same survey instrument was to be used in the two countries, substantial effort was made to appropriately standardize the instrument and avoid cultural differences in interpreting specific questions. This was done with the help of experts in the field in the two respective countries and by running a pilot survey before finalizing the survey instrument. 
A total of 1,087 firms from China and India responded to our survey. The sample includes 925 useful responses, among which 420 are from China, and 505 from India. Firms from the automotive components sector, the software sector, and the green-biotech sector constitute $41 \%, 38 \%$, and $21 \%$, respectively of the total sample of firms (see Table 1).

Table 1

Firm sample divided by country and sector.

\begin{tabular}{cccc}
\hline \multirow{2}{*}{ Sector } & \multicolumn{3}{c}{ Country } \\
\cline { 2 - 4 } & China & India & Total \\
\hline Automotive component & 151 & 227 & 378 \\
Software & 182 & 171 & 353 \\
Green-biotech & 87 & 107 & 194 \\
Total & 420 & 505 & 925 \\
\hline
\end{tabular}

\subsection{Statistical analysis}

To investigate the differences in ICS choices among firms in China and India, we first compare the means of the specific choices in the two countries. We carry out a series of tests of proportions to check if the differences are significant. Then, using a multinomial logistic (MNL) regression model, we analyze firms' propensities to implement different types of ICS given the presence of some specific resources and capabilities within the firm. Using MNL, the dependent variable (the type of ICS), can be analyzed as a multi-categorical variable. Thus, the model can estimate the effect of the independent variables on the probability (differential odds) that one of the three alternatives (cost leadership, differentiation, and hybrid strategy) will be selected by each firm. To assess the validity of the model, we ran the generic Hausman test. For easier and better comparison of the empirical results, coefficients are computed and then converted into quasi-elasticities. Quasi-elasticities are normally considered more reliable and superior measures compared to the coefficients themselves by their ease of interpretation. 


\subsection{Measures}

\subsubsection{Dependent variable}

The dependent variable is a categorical variable that indicates the type of ICS used by firms operating in international markets: (0) no strategy applied (baseline in the regression); (1) cost leadership strategy, corresponding to a firm's ability to offer a lower costs than competitors within the international markets in which it operates; (2) differentiation strategy, corresponding to a firm's ability to offer better quality than its competitors, or new products/services within the international markets in which it operates; (3) hybrid strategy, corresponding to a firm's ability to access with both cost leadership and differentiation strategies. Since the firms' ICS to access a market in developing countries may be different from the one used to access a market in developed countries, in our econometric analysis we use two sets of categorical dependent variables for each of the two markets.

\subsubsection{Independent variables}

We selected the following relevant variables measuring firms' resources and capabilities.

Firstly, the qualification of human resources is represented by a dummy variable (human resources) that takes the value 1 if the percentage of employees with a university degree or postgraduate studies is greater than the mean of the country where the firm is located, and 0 otherwise.

Secondly, the quality of the technological resources of the firm is accounted for by three different proxies related both to resources connected to technological capacity and to technological investment in innovation. For the former we asked the firms whether their machinery and equipment were more advanced than the average of the industry in their country. The relative dummy variable, technological capacity, takes the value 1 if this is the case and 0 otherwise. For technology investments, we considered both the presence of a R\&D department and the presence of intramural $R \& D$ as defined in the Oslo Manual (2005). The two dummies are equal to 1 if that is the case, and 0 otherwise. 
Thirdly, we use two types of proxies for the firms' organizational capabilities. One is organization techniques. We asked the firms whether in 2007 they used a series of complex production organization systems, such as quality control systems, just-in-time, continuous improvement, quality circles and team work, and internal manuals. Similar to Padilla-Perez (2006) and Plechero and Chaminade (2010a), we proxy the organization techniques by counting the number of systems of production used by the firm. Since many of the firms in this study responded that they use several systems of production and only 19 firms use none, a dummy variable (systems of production) valuing 1 if the firm used more than 3 systems of production (the maximum was 6) and 0 otherwise is built. The other measure for organization capabilities is quality certification. We asked the firms for the number of quality certifications, such as ISO, they had in 2007. We then created a dummy variable (quality certification) taking the value 1 if the firm had at least one, and 0 otherwise.

\subsubsection{Control variables}

To isolate the effect of a firm's resources and competences on ICS choices, we incorporate several control variables at the firm level into the regression model. Firstly, we control for country and create a dummy variable (country) equal to 1 if the firm belongs to China, else 0 (for India). Secondly, since the firms in our database belong to different industrial sectors, we created a set of dummy variables (auto, software, biotech) equal to 1 if the firm belongs to the indicated sector, and 0 otherwise. Thirdly, we control for firm size, creating three dummy variables (small, medium, large) based on the sales volume: less than 2 million US dollars, between 2 and 10 million US dollars, and more than 10 million US dollars, respectively. The variables equal 1 when the firm belongs to that specific size category and 0 otherwise. Fourthly, we control for the age of the firms (firm age), because it can be considered to be a good proxy for valuing the firm's experiences in strategic decision-making. We use a continuous variable indicating the number of years since the founding of the firm. Fifthly, we control for the type of ownership of the firm (foreign ownership) which equals 1 if the firm has some participation of foreign capital and 0 otherwise. 
Furthermore, we control for firm's organizational type, because it may affect the ability of the firm to obtain resources, and therefore indirectly to develop ICS. We create three dummy variables (head-office, subsidiary, single), equal to 1 when the firm is of that type, and 0 otherwise. Lastly, we control for the openness of the firm in terms of foreign sales (for-sale) by using the percentage of foreign sales in 2007.

\section{Empirical results}

4.1. Chinese and Indian competitive strategies to access domestic and international markets

Before presenting the results of the analysis, we report some descriptive statistics (see Table 2) that give a snapshot of the sample firms and provide some initial insights about the strategies pursued by sample firms during the year 2007 to access different markets. We include in the first and second part of the table some general and structural information about the firms and their average percentage of resources and capabilities. The last part of the table reports some statistical evidence about firm strategies in domestic markets, LDCM and DCM, respectively. As we can observe from the mean values of the competitive strategies, the results show very clearly that the most common strategy pursued by the sample firms is "differentiation" not only in the domestic market, where it is implemented by $51 \%$ of the firms, but also in the international markets where it is used by $21 \%$ of the firms both in LDCM and DCM. Besides the presence of pure strategies (cost leadership or differentiation) in both domestic markets and international markets, we can observe that certain firms, in particular in the domestic market, use hybrid strategy as well (32\% in the domestic market, 6\% in LDCM and 6\% in DCM). 
Table 2

Descriptive statistics of Sample Firms.

\begin{tabular}{|c|c|c|c|}
\hline Variable & Description & Mean & Std. Deviation \\
\hline \multirow[t]{4}{*}{ Size (Sales) } & Small (<2 million USD) & 0.51 & 0.50 \\
\hline & Medium (2-10 million & 0.30 & 0.46 \\
\hline & USD) & & \\
\hline & Large (>10 million USD) & 0.19 & 0.40 \\
\hline Age & Age & 11.31 & 9.92 \\
\hline Foreign Ownership & Foreign ownership & 0.21 & 0.41 \\
\hline \multirow[t]{3}{*}{ Organizational type } & A single unit & 0.63 & 0.48 \\
\hline & Head office of a group & 0.07 & 0.26 \\
\hline & Subsidiary of a group & 0.30 & 0.46 \\
\hline Foreign sale & Percentage of foreign sale & 16.89 & 31.05 \\
\hline Human resources & $\begin{array}{l}\text { University degree or } \\
\text { postgraduate }\end{array}$ & 47.72 & 37.84 \\
\hline Technological resources & Above average & 0.27 & 0.44 \\
\hline Organizational techniques & $\begin{array}{l}\text { Number of systems of } \\
\text { production }\end{array}$ & 2.94 & 1.39 \\
\hline Quality certification & $\begin{array}{c}\text { Number of quality } \\
\text { certifications }\end{array}$ & 0.74 & 0.44 \\
\hline \multirow[t]{2}{*}{ R\&D investment } & R\&D department & 0.59 & 0.49 \\
\hline & Intramural R\&D & 0.54 & 0.50 \\
\hline \multirow[t]{3}{*}{ Domestic strategy } & Cost leadership & 0.11 & 0.31 \\
\hline & Differentiation & 0.51 & 0.50 \\
\hline & Hybrid & 0.32 & 0.47 \\
\hline \multirow{3}{*}{$\begin{array}{l}\text { Developing countries } \\
\text { market strategy (LDCM) }\end{array}$} & Cost leadership & 0.06 & 0.24 \\
\hline & Differentiation & 0.21 & 0.41 \\
\hline & Hybrid & 0.06 & 0.24 \\
\hline \multirow{3}{*}{$\begin{array}{l}\text { Developed countries market } \\
\text { strategy (DCM) }\end{array}$} & Cost leadership & 0.04 & 0.19 \\
\hline & Differentiation & 0.21 & 0.41 \\
\hline & Hybrid & 0.06 & 0.24 \\
\hline
\end{tabular}

In terms of cross-country differences, Table 3 reports the results of tests of proportions for the two countries in relation to their competitive strategies. As we can notice, the strategies used by Chinese and Indian firms are quite different both in the domestic and international markets. In the domestic markets, for example, the results show that Indian firms use cost leadership (18\%) much more than Chinese 
firms $(2 \%)$, while Chinese firms have a higher preference $(55 \%)$ than Indian firms (47\%) for differentiation strategy. The test of proportion does not show any significant difference for the hybrid strategy. The higher use of cost leadership strategy by Indian firms is also confirmed in the international markets where the percentage of Indian firms employing this strategy is 10 times more than the percentage of Chinese firms in LDCM and 7 times more in DCM. Compared to Chinese firms, the use of differentiation strategy is also more wide-spread among Indian firms in international markets; the Indian firms use this strategy 3 times more in LDCM and 4 times more in DCM than Chinese firms. In the case of hybrid strategy, the differences between the Indian and Chinese firms are not very significant; only in LDCM a significantly larger proportion of Chinese firms adopt this strategy.

\section{Table 3}

Results of tests of proportions for country differences in the competitive strategies.

\begin{tabular}{ccccc}
\hline Variable & Description & $\begin{array}{c}\text { Mean for } \\
\text { Chinese firms }\end{array}$ & $\begin{array}{c}\text { Mean for } \\
\text { Indian firms }\end{array}$ & $z$ \\
\hline Domestic strategy & Cost leadership & 0.02 & 0.18 & $-7.47^{* * *}$ \\
& Differentiation & 0.55 & 0.47 & $2.40^{* *}$ \\
& Hybrid & 0.32 & 0.31 & 0.06 \\
Developing countries & Cost leadership & 0.01 & 0.10 & $-5.50^{* * *}$ \\
market strategy & & & & \\
(LDCM) & & & & \\
& Differentiation & 0.10 & 0.31 & $-7.55^{* * *}$ \\
Developed countries & Hybrid & 0.08 & 0.04 & $2.95^{* * *}$ \\
market strategy & Cost leadership & 0.01 & 0.07 & $-4.56^{* * *}$ \\
(DCM) & & & & \\
& & & & $-8.84^{* * *}$ \\
& Differentiation & 0.08 & 0.32 & -0.75 \\
\hline
\end{tabular}

Note: Significance levels: $1 \%{ }^{* * *} ; 5 \%{ }^{* *} ; 10 \% *$.

4.2. Factors affecting the firms' international competitive strategy (ICS)

Table 4 reports the results of the MNL analysis in terms of quasi-elasticities for competitive strategies in LDCM (model 1) and in DCM (model 2), respectively. 
Table 4

Estimated quasi-elasticity from multinomial logistic models for LDCM and DCM.

\begin{tabular}{|c|c|c|c|c|c|c|c|c|}
\hline & \multicolumn{4}{|c|}{ Model 1 Developing countries market (LDCM) } & \multicolumn{4}{|c|}{ Model 2 Developed countries market (DCM) } \\
\hline & Cost leadership & Differentiation & Hybrid & None & Cost leadership & Differentiation & Hybrid & None \\
\hline $\begin{array}{l}\text { Human } \\
\text { resources }\end{array}$ & $0.01(0.01)$ & $0.04(0.04)$ & $0.00(0.02)$ & $-0.05(0.04)$ & $0.02 * *(0.01)$ & $0.08 * *(0.03)$ & $0.01(0.02)$ & $-0.11 * *(0.04)$ \\
\hline $\begin{array}{l}\text { Technologic } \\
\text { al capability }\end{array}$ & $-0.00(0.01)$ & $0.10 * *(0.05)$ & $0.01(0.02)$ & $-0.10 * *(0.05)$ & $0.01(0.01)$ & $0.08 *(0.04)$ & $0.04 *(0.02)$ & $-0.13^{* * *}(0.05)$ \\
\hline $\begin{array}{l}\text { R\&D } \\
\text { department }\end{array}$ & $0.01(0.01)$ & $0.02(0.04)$ & $0.01(0.02)$ & $-0.04(0.04)$ & $-0.01(0.01)$ & $0.03(0.03)$ & $-0.01(0.02)$ & $-0.01(0.04)$ \\
\hline Intra R\&D & $0.01(0.01)$ & $0.08 * *(0.04)$ & $0.03(0.02)$ & $-0.11^{* * *}(0.04)$ & $0.02 *(0.01)$ & $0.03(0.03)$ & $0.03(0.02)$ & $-0.07 *(0.04)$ \\
\hline $\begin{array}{l}\text { Organization } \\
\text { techniques }\end{array}$ & $-0.02 *(0.01)$ & $0.14^{* * *}(0.05)$ & $0.06 * *(0.03)$ & $-0.18 * * *(0.06)$ & $0.02(0.01)$ & $0.11 * *(0.05)$ & $0.10 * * *(0.03)$ & $-0.22^{* * *}(0.06)$ \\
\hline $\begin{array}{l}\text { Quality } \\
\text { certification }\end{array}$ & $0.01 * *(0.01)$ & $0.08 * *(0.03)$ & $0.03 *(0.02)$ & $-0.12 * * *(0.04)$ & $-0.01(0.01)$ & $0.06 * *(0.03)$ & $0.02(0.02)$ & $-0.07 *(0.04)$ \\
\hline Country & $-0.04^{* * *}(0.01)$ & $-0.32^{* * *}(0.04)$ & $-0.01(0.02)$ & $0.37^{* * *}(0.05)$ & $-0.06^{* * *}(0.02)$ & $-0.30 * * *(0.04)$ & $-0.07^{* * *}(0.02)$ & $0.43^{* * *}(0.05)$ \\
\hline Software & $0.06 * *(0.03)$ & $0.07(0.05)$ & $-0.02(0.02)$ & $-0.11 *(0.06)$ & $0.02(0.01)$ & $0.14 * * *(0.05)$ & $-0.02(0.02)$ & $-0.14 * *(0.06)$ \\
\hline Biotech & $-0.00(0.01)$ & $0.17^{* * *}(0.06)$ & $-0.04 * *(0.01)$ & $-0.13^{* *}(0.06)$ & $-0.01(0.01)$ & $0.10 *(0.05)$ & $-0.05 *(0.01)$ & $-0.04(0.06)$ \\
\hline Large_sale & $0.02(0.01)$ & $0.12^{* *}(0.05)$ & $0.01(0.02)$ & $-0.16 * * *(0.06)$ & $-0.01(0.01)$ & $0.04(0.04)$ & $-0.00(0.02)$ & $-0.03(0.05)$ \\
\hline Firm age & $0.00(0.00)$ & $0.003^{* *}(0.001)$ & $-0.00(0.00)$ & $-0.004 * *(0.002)$ & $0.001 *(0.000)$ & $0.003^{* *}(0.001)$ & $0.001 *(0.001)$ & $-0.004 * * *(0.002)$ \\
\hline $\begin{array}{l}\text { Foreign } \\
\text { ownership }\end{array}$ & $0.00(0.01)$ & $0.05(0.05)$ & $0.01(0.02)$ & $-0.06(0.06)$ & $0.01(0.01)$ & $0.03(0.04)$ & $-0.01(0.02)$ & $-0.02(0.05)$ \\
\hline Headoffice & $-0.02 * *(0.01)$ & $-0.04(0.05)$ & $0.02(0.04)$ & $0.05(0.06)$ & $0.00(0.01)$ & $0.04(0.06)$ & $0.01(0.03)$ & $-0.05(0.07)$ \\
\hline Subsidiary & $-0.01(0.01)$ & $0.02(0.04)$ & $0.01(0.02)$ & $-0.02(0.04)$ & $0.00(0.01)$ & $0.08 * *(0.04)$ & $-0.02(0.02)$ & -0.07 (0.04) \\
\hline For_sale & $0.001^{* * *}(0.000)$ & $0.01 * * *(0.00)$ & $0.001 * * *(0.000)$ & $-0.01^{* * *}(0.00)$ & $0.0003^{* *}(0.0001)$ & $0.004^{* * *}(0.001)$ & $0.001 * * *(0.000)$ & $-0.01^{* * *}(0.00)$ \\
\hline
\end{tabular}

Note: ${ }^{*} \mathrm{p}<0.10,{ }^{* *} \mathrm{p}<0.05,{ }^{* * *} \mathrm{p}<0.01$. Standard errors in parenthesis. Baseline $=$ no strategy 
The quasi-elasticity assesses the simultaneous effect of each of the regressor variables on the probabilities of the four distinct strategies (cost leadership, differentiation, hybrid and none). In this way, it is possible to observe how the probability of the firm's adoption of the different strategies changes when the regressor variables increase by one per cent (or one unit).

Qualified human resources. The estimates reported in Table 4 suggest that human resources affect firms' ICS only when they access DCM. The quasi-elasticity for qualified human resources indicates that with an increase in the percentage of qualified human resources, firms have a higher propensity to access DCM through a differentiation strategy. The relevant estimated elasticity $(0.08)$ is positive and significant at $5 \%$. For this $\mathrm{r}$ egressor variable, we also observe a positive (though smaller) effect on the cost leadership strategy. The elasticity is 0.02 and significant at 5\%. Moreover, human resources in DCM support cost leadership or differentiation strategies but not both simultaneously (hybrid). So our analysis only partly supports hypothesis 1 and does so only for strategies in DCM: Firms with a high percentage of qualified human resources are more likely to pursue differentiation or cost leadership strategies to access international markets in developed countries.

Technological resources. The technological capability of the firm (expressed by the proxy related to the sophistication of machinery and equipment) increases the likelihood that a given firm will use a differentiation strategy to access LDCM as well as DCM (estimated elasticity being 0.10 with $\mathrm{P}<0.05$ for $\mathrm{LDCM}$ and 0.08 with $\mathrm{P}<0.10$ for DCM). Such resources also positively affect the probability of using hybrid strategies, but only in DCM, though the effect is somewhat smaller than that for differentiation (Model 2: 0.04 with $\mathrm{P}<0.10$ ).

Among the technological investments of a firm, it is interesting to notice that the presence of a R\&D department does not seem to affect strategic choices to access international markets. However, intramural R\&D (intraR\&D) increases the chances that the firm will utilize differentiation strategy to access LDCM (an elasticity of 0.08 with $\mathrm{P}<0.05)$. It also marginally increases the chance that cost leadership strategy 
will be used to access DCM (an elasticity of 0.02 with $\mathrm{P}<0.05$ ). Apparently, intramural R\&D helps firms differentiate their products in LDCM and use cost reduction strategies in DCM.

Broadly, the empirical results confirm hypothesis 2 but there is a distinction between the two markets: Firms with advanced technological resources are likely to pursue differentiation and/or hybrid strategies to access international markets.

Organizational capabilities. The results of the regressions indicate that differentiation and hybrid strategies are more likely to be used by firms characterized by higher levels of organizational capabilities (measured by higher adoption rates of various organizational techniques) to access both LDCM and DCM. The presence of quality certification in the firm also positively affects the chances of using differentiation and hybrid strategies to access LDCM, although the magnitude of the effect is much higher for differentiation strategy. In this market, there is also a very small but significant effect on cost strategy. For DCM, however, it only facilitates differentiation strategy. In this case, the results seem partially to confirm hypothesis 3: firms with high level organizational capabilities are more likely to pursue differentiation and/or hybrid strategy to access international markets.

Other firm characteristics: Besides the role of resources and capabilities discussed above, the empirical results provide some interesting insights on the role of other firm characteristics influencing firms' international strategic choices.

The country effect: The country in which firms are located influences their ICS choices when entering international markets. The econometric results suggest that there is more specialization in the international markets among Indian firms than among Chinese firms. The Indian firms, ceteris paribus, have a higher probability of employing cost leadership and differentiation strategies in all types of international markets. The negative and significant elasticity of the variable country related to differentiation $(<-0.30$ with $\mathrm{P}<0.01)$ in both $\mathrm{LDCM}$ and $\mathrm{DCM}$ underlines that the difference is particularly evident for the differentiation strategy. 
With respect to the hybrid strategy, there are some differences between the simple descriptive statistics reported in Table 3 and the econometric analysis. The latter results show that Indian firms are more specialized than Chinese firms in developing hybrid strategies in DCM; this is probably the result of a combined effect of country differences and the specific micro-characteristics of the firms.

Sector specificities: The sectors to which the firms belong may influence their ICS choices. As Pavitt (1984) suggests, firms may have different types of knowledge bases and sources of knowledge in different industrial sectors, depending on the specific driver of technological change prevailing in an industry. From our analysis it emerges that firms in the software industry have a higher propensity than those in the automotive industry (the excluded variable) to develop a cost leadership strategy in LDCM, and a differentiation strategy in DCM. Firms in the biotech industry have, instead, a more general propensity to pursue international differentiation strategy, but a lower propensity to pursue hybrid strategy.

Structural characteristics of firms: Some other characteristics of firms seem to influence the choices of ICSs. For example, larger firms show a higher probability to use differentiation strategy when accessing LDCM. Older firms have a slightly higher propensity to use all three strategies when accessing DCM, but to only use differentiation strategy when accessing LDCM. Firms with a high percentage of foreign sales seem to prefer all three strategies (over not having any) when accessing international markets. The specific organizational form may also influence the ICS choice: subsidiaries of an enterprise group have a higher probability of developing a differentiation strategy when accessing DCM.

\section{Discussion and conclusions}

Through firm-level analysis, this study explores the correlation between various types of ICSs Chinese and Indian firms pursue to obtain competitive advantages in the global market. More specifically, we examine how these strategic choices are related to firms' resources and capabilities. A large sample survey of firms belonging to three sectors - auto components, biotech and software - in one Chinese region and 
one Indian region was used for this purpose.

The findings show that in both domestic and international markets, Chinese and Indian firms are moving away from a situation in which they do not have a well defined ICS and towards developing not only cost leadership strategies but also differentiation and hybrid strategies. This indicates that firms from the two countries have started to confront worldwide business competition in a dynamic way. Some differences emerge when we compare the strategies pursued by these firms in LDCM and DCM but in both locations apart from cost leadership the firms are increasingly using differentiation and hybrid strategies. In particular, competing in the international market with differentiation strategy (the most common strategy used by the firms in the sample) and hybrid strategy indicates that Chinese and Indian firms not only make good use of their low cost advantage, but also try to distinguish themselves from their competitors in order to create a favorable brand image by offering high-quality products and services, or by developing a certain flexibility to stay in the market. This finding is consistent with many recent studies on China and India's development, such as Altenburg et al. (2008), Chaminade and Vang (2008), Plechero and Chaminade (2010b), Saran and Guo (2005) which acknowledge the transition of Chinese and Indian firms - traditionally more involved at international level in the production of low value activities - from production-based activities to innovation-based activities. The results of our study also contradict Porter's idea (Porter1980, 1985) that firms attempting to pursue more than one generic competitive strategy are perceived as being stuck in the middle. Actually, we show that both Chinese and Indian firms pursue pure as well as hybrid strategies. These findings confirm some existing studies such as Gopalakrishna and Subrananian (2001), which examine the hybrid strategies undertaken by Indian firms in the case of consumer goods industries, but only for the domestic market. Our research demonstrates that this is also true in the international market, advancing the knowledge of competitive strategy studies within the strategic management discipline. 
When comparing the two countries, our main findings show that even though, in their respective domestic markets, Chinese firms seem to be more specialized in differentiation strategy than Indian firms, in the international market the proportion of Indian firms that are pursuing competitive strategies, and in particular differentiation strategy, is higher. This may partly be due to the fact that the Chinese domestic market is much larger than that of India and seems to be maturing faster (Johnson and Tellis, 2007). The large domestic market size and the emergence of multiple customer segments seems to be creating differentiation options for Chinese firms, which do not seem to be available on the same scale for Indian firms in their domestic market. However, as many academic writings and industry reports suggests (e.g. Balasubramanyan, 2011; Just-auto.com, 2010), Indian firms are increasingly building differentiation or, to some extent, hybrid strategies to access international markets, partly because they do not have the low cost advantage that Chinese firms enjoy. Consequently, differentiation seems to be the emerging appropriate option for Indian firms. Indeed, as confirmed in other studies (Chaminade and Vang, 2008; Niosi and Tschang, 2009), while Chinese firms are focusing more on their domestic market, Indian firms seem to be exploring the international market more sharply in recent years. This is in line with their historical tradition of international cooperation and sourcing in sectors like software. In addition to the survey, during 2009 we conducted a series of case studies both in Jing-Jin-Ji and Pune regions that further confirm this trend.

A detailed analysis of firm-level characteristics shows that the pursuit of different types of ICS depends not only on where the firms are located and to which sectors they belong, but also on firms' resources and capabilities. Table 5 summarizes the key results. A few interesting insights about the role of various resources are worth noting and can form the basis of some further research. 
Table 5

Firm Resources and Their Impact on International Competition Strategies: A Summary

\begin{tabular}{|c|c|c|c|c|c|c|c|c|}
\hline \multirow{3}{*}{$\begin{array}{l}\text { Firm } \\
\text { Resources }\end{array}$} & \multicolumn{4}{|c|}{$\begin{array}{l}\text { Strategies for developing countries market } \\
\qquad(\text { LDCM) }\end{array}$} & \multicolumn{4}{|c|}{$\begin{array}{l}\text { Strategies for developed countries market } \\
\qquad(\mathrm{DCM})\end{array}$} \\
\hline & Cost & & & & Cost & & & \\
\hline & leadership & Differentiation & Hybrid & None & leadership & Differentiation & Hybrid & None \\
\hline Human & & & & & & & & \\
\hline resources & $\mathrm{N}$ & $\mathrm{N}$ & $\mathrm{N}$ & $\mathrm{N}$ & + & + & $\mathrm{N}$ & - \\
\hline Technologica & & & & & & & & \\
\hline capability & $\mathrm{N}$ & + & $\mathrm{N}$ & - & $\mathrm{N}$ & + & + & - \\
\hline $\mathrm{R} \& \mathrm{D}$ & & & & & & & & \\
\hline department & $\mathrm{N}$ & $\mathrm{N}$ & $\mathrm{N}$ & $\mathrm{N}$ & $\mathrm{N}$ & $\mathrm{N}$ & $\mathrm{N}$ & $\mathrm{N}$ \\
\hline Intra R\&D & $\mathrm{N}$ & + & $\mathrm{N}$ & - & + & $\mathrm{N}$ & $\mathrm{N}$ & - \\
\hline Organization & & & & & & & & \\
\hline techniques & - & + & + & - & $\mathrm{N}$ & + & + & - \\
\hline Quality & & & & & & & & \\
\hline certification & + & + & + & - & $\mathrm{N}$ & + & $\mathrm{N}$ & - \\
\hline
\end{tabular}

Source: Based on Table 4. N indicates no significant effect.

Human resources (or the availability of well qualified persons) do not seem to be critical for Indian and Chinese firms to access LDCM in the current situation as they do not impact any of the strategic choices for this market. However, the presence of such resources in the firm helps strategically access DCM, both through cost leadership as well as differentiation. The results show that human resources are indeed important in affecting the pursuit of competitive strategy in the most advanced markets. These may also partly reflect the heterogeneity in human resources that we have not been able to capture in our survey. If the DCM is more lucrative and, at the same time, more demanding, one would require a variety of capabilities and resources to access and compete effectively in the market. Some qualified human resources may be able to reduce costs, while others may help develop differentiated products and services.

The impact of technology resources on firms' ICS choices is also interesting. The technology capacity embedded in advanced machinery and equipment facilitates accessing LDCM through differentiation, but facilitates accessing DCM either 
through differentiation or hybrid strategies. Apparently, embodied technologies have helped Indian and Chinese firms implement process driven changes resulting both in cost savings and some product differentiation. While the latter advantage is helping firms access both LDCM and DCM, the former seems to be critical only for DCM through hybrid strategy. Once other resources are controlled for, having an R\&D department per se does not make a difference in firms' ICS choices. But intra-mural $R \& D$ seems to be focused more on reducing costs (through process changes or making products more manufacturable) or making some modifications in the product offerings. While the associated cost advantage is being leveraged to access DCM, some product modifications are also being used to access LDCM.

Organizational capabilities also have a significant impact on Indian and Chinese firms' strategic choices to access foreign markets. The information captured in "organizational techniques" (complex production systems, continuous improvement, just-in-time, quality circles, etc.) partly encompasses the resources available to those firms that have some quality certification. Interestingly, advanced organizational processes seem to facilitate the strategic movement away from pure cost leadership to either differentiation or hybrid strategies. Apparently, continuous improvement and complex production systems, apart from providing cost advantages, are creating opportunities for product development and/or modifications. The impact of quality certification is interesting. Some of the systems and practices adopted by firms while getting certified seem to help reduce costs as well as improve product differentiation. It is possible that these product modifications are incremental but are good enough to enable the use of all three strategies to access LDCM and focus on some differentiation for the DCM. Putting a variety of quality and other organizational systems and practices in place might help firms in transition economies explore both cost leadership and differentiation strategies in order to access international markets.

This study has several implications for business practitioners. It provides firms from emerging markets with a frame of reference that they can use to achieve an optimal 
strategic decision in international markets since various resources or capabilities have different tendencies to increase the possibility of cost cutting or product differentiation. Managers also need to be aware that, although they should choose an appropriate competitive strategy in international markets, their choice is often constrained by the sector they are in and by firm size, age, organizational form, and degree of openness. This study offers not only valuable information to Chinese and Indian firms that need to make strategic decisions related to entering international markets, but also some insight to foreign multinationals that seek to enter Chinese and Indian markets or compete with Chinese and Indian rivals at the global level. For example, multinationals competing against Chinese and Indian firms should also take a dynamic approach to making ICS choices in different LDCM and DCM market locations.

To conclude, while our results provide some interesting insights on the relevance of different firm resources in the internationalization process, it needs to be emphasized that we have captured Indian and Chinese firms at a stage when their global strategies are still evolving and the results may change as these economies mature. Being the first database jointly developed by scholars in China and India, a variety of measurement issues still need to be resolved. For example, the information on ICS used by the responding firm is essentially a perception-based variable as reflected in the responses of senior managers. Similarly, measurement of technological and other resources will need further attention. Even though we used the same questionnaire in the two countries, the methodology to collect the answers has been partially different (mainly by phone call in China and face to face in India). Finally, as is often the case in developing countries, it is not possible to calculate the total population of firms with full accuracy and thus, it is difficult to say beyond doubt whether the sample or the response rate in the two specific clusters analyzed is representative . However, the results provide useful pointers for further research. 


\section{References}

Acquaah M, Yasai-Ardekan $M$. Does the implementation of a combination competitive strategy yield incremental performance benefits? A new perspective from a transition economy in Sub-Saharan Africa. J Bus Res 2008; 61:346-354.

Allred B B, Swan K S. Contextual influences on international subsidiaries' product technology strategy. J Int Manage 2004; 10:259-286.

Altenburg T, Schmitz H, Stamm A. Breakthrough? China's and India's transition from production to innovation. World Dev 2008; 36(2):325-344.

Barney J B. Firm resources and sustained competitive advantage. J Manage 1991; 17:99-120.

Basant R, Chandra P. Role of educational and R\&D institutions in city clusters: An exploratory study of Bangalore and Pune Regions in India. World Dev 2007; 35(6):1037-1055.

Bhattacharya S, Nath $\mathrm{P}$. Using patent statistics as a measure of technological assertiveness: A China - India comparison. Curr Sci 2002; 83(1):23-29.

Blonigen B A, Taylor C T. R\&D intensity and acquisitions in high technology industries: Evidence from the US electronic and electrical equipment industries. J Ind Econ 2000; 48(1):47-70.

Bruton $\mathrm{G} \mathrm{D}$, Lohrke $\mathrm{F} \mathrm{T}$, Lu $\mathrm{J} \mathrm{W}$. The evolving definition of what comprises international strategic management research. J Int Manage 2004; 10:413-429.

Chaminade C, Vang J. Globalization of knowledge production and regional innovation policy: Supporting specialized hubs in the Bangalore software industry. Res Policy 2008; 37(10):1684-1696.

China Knowledge, China economy at regional level: Major economic circles. http:/ /www.chinaknowledge.com/Business/CBGdetails.aspx?subchap=1\&cont ent=5\#MarjorEconomicCircles, access on 06 August 2010.

Cohen W M, Levinthal D A. Absorptive capacity: A new perspective on learning and innovation. Administrative Science Quarterly 1990; 35(1):128-152.

Collis D. A resource-based analysis of global competition: The case of the bearings 
industry, Strateg Manage J 1991; 12:49-68.

Dominguez L, Sequeira C. Determinants of LDC exporters' performance: A cross-national study. J Int Bus Stud 1993; 24:19-40.

Dunning J H. Toward an eclectic theory of international production: Some empirical tests. J Int Bus Stud 1980; 11:9-31.

Dunning $\mathrm{J} \mathrm{H}$. The eclectic paradigm of international production: A restatement and some possible extensions. J Int Bus Stud 1988; 19:1-31.

Fahy J. A resource-based analysis of sustainable competitive advantage in a global environment. Int Bus Rev 2002; 11:57-78.

Gopalakrishna P, Subramanian R. Revisiting the pure versus hybrid dilemma: Porter's generic strategies in a developing economy. J Glob Mark 2001; 15:61-79.

Grant R M. Resource-based theory of competitive advantage: Implications for strategy formulation. Calif Manage Rev 1991; Spring:114-135.

Guan J C, Yam R C M, Tang E P Y, Laud A K W. Innovation strategy and performance during economic transition: Evidences in Beijing, China. Res Policy 2009; 38(5):802-812

Hatch N W, Dyer J H. Human capital and learning as a source of sustainable competitive advantage. Strateg Manage J 2004; 25:1155-1178.

Hill C W L. Differentiation versus low cost or differentiation and low cost: A contingency framework. Acad of Manage J 1988; 13(3):401-412.

Hitt M, Bierman L, Shimizu K, Kochhar R. Direct and moderating effects of human capital on strategy and performance in professional service firms: A resource-based perspective. Acad of Manage J 2001; 44(1):13-28

Hymer S. The international operation of national firms: A study of direct foreign investment. Cambridge, MA: MIT Press; 1976.

Huggins $\mathrm{R}$, Demirbag $\mathrm{M}$, Iankova V. Global knowledge and R\&D foreign direct investment flows: Recent patterns in Asia Pacific, Europe, and North America. Int Rev Appl Econ 2007; 21 (3):437-451. 
Johnson J, Tellis G. Drivers of success for market entry into China and India. Marshall Research Paper Series, Working Paper MKT 10-07; 2007.

Just-auto.com. Analysis: India's rising manufacturing labor costs overtake China. Http://www.just-auto.com/analysis/indians-rising-manufacturing-labour-cos ts-overtake-china_id106790.aspx. Accessed December 10, 2010.

Kostoff R N, Bhattacharya S, Pecht M. Assessment of China's and India's science and technology literature: Introduction, background, and approach. Technol Forecast Soc Change 2007; 74:1519-1538.

Lin B W, Lee Y, Hung S C. R\&D intensity and commercialization orientation effects on financial performance. J Bus Res 2006; 59:679-685.

Luo Y D, Zhao H X. Corporate link and competitive strategy in multinational enterprises: A perspective from subsidiaries seeking host market penetration. $\mathrm{J}$ Int Manage 2004; 10:77-105.

Mani, Sunil. Is India Becoming More Innovative Since 1991? Some Disquieting Features. Economic and Political Weekly 2009; XLIV (46): 41-51.

Mascarenhas B, Baveja A, Jamil M. Dynamics of core competencies in leading multinational companies. Calif Manage Rev 1998; 40(4):117-132.

MCCIA, Profile and analysis of Pune manufacturing Inc. An Intelligence Report on Growth of Pune Industries, Mahratta Chamber of Commerce, Industries and Agriculture, 2008.

Miller D. The generic strategy trap. J Bus Strateg 1992; 13:37-41.

Miller D, Friesen P H. Porter's generic strategies and performance: An empirical examination with American data. Part I: Testing Porter. Organ Stud 1986a; $7: 37-55$

Miller D, Friesen P H. Porter's generic strategies and performance: An empirical examination with American data. Part II: Performance Implications. Organ Stud $1986 b ; 7: 255-261$

Morrison A, Roth K. A taxonomy of business-level strategies in global industries. Strateg Manage J 1992; 13:399-418. 
Mu R P, Qu W. The development of science and technology in China: A comparison with India and the United States. Technol Soc 2008; 30:319-329.

Niosi J, Tschang F T. The strategies of Chinese and Indian software multinationals: implications for internationalization theory. Ind Corp Change 2009; 18(2):269-294.

O’Brien J P. The capital structure implications of pursuing a strategy of innovation. Strateg Manage J 2003; 24(5):415-431.

OECD, Staying competitive in the global economy. Moving up the value chain. Report 2008.

Ortega $M \quad J$ R. Competitive strategies and firm performance: Technological capabilities' moderating roles. J Bus Res 2010; 63(12):1273-1281.

Oslo Manual, Guidelines for collecting and interpreting innovation data, $3^{\text {rd }}$ Edition, OECD, 2005.

Padilla-Perez R. Foreign direct investment and regional technological capabilities: The case of the electronics industry in Mexico. SPRU: Science Policy Research Units, Sussex University PhD Dissertation; 2006.

Pavitt K. Sectoral patterns of technical change: Towards a taxonomy and a theory. Res Policy 1984; 13(6):343-373.

Pertusa-Ortega E, Molina-Azorin J F, Claver-Cortes E. Competitive strategies and firm performance: A comparative analysis of pure, hybrid and "stuck-in-the-middle" strategies in Spanish firms. $\mathrm{Br} \mathrm{J}$ Manage 2009; 20(4):508-523.

Peteraf N A. The cornerstones of competitive advantage: A resource-based view. Strateg Manage J 1993; 14(3):179-191.

Peng M W. From China strategy to global Strategy. Asia Pac J Manage 2005; $22(2): 123-141$.

Plechero M, Chaminade C. Different competences, different modes in the globalization of innovation? A comparative study of the Pune and Beijing regions. CircleWP 12; 2010a. 
Plechero M, Chaminade C. From new to the firm to new to the world. Effect of geographical proximity and technological capabilities on the degree of novelty in emerging economies. CircleWP 12; 2010b.

Porter M E. Competitive strategy: techniques for analyzing industries and competitors. NY: Free Press; 1980.

Porter M E. Competitive advantage: Creating and sustaining superior performance. NY: Free Press; 1985.

Porter M E. Towards a dynamic theory of strategy. Strateg Manage J 1991; 12:95-117.

Porter M E. What is strategy? Harv Bus Rev 1996; 74:61-78.

Prajogo D I, Sohal A S. The integration of TQM and technology/R\&D management in determining quality and innovation performance. Omega 2006; 34:296-312.

Prasad V K, Ramamurthy K, Naidu G M. The influence of internet-marketing integration on marketing competencies and export performance. J Int Mark $2001 ; 9(4): 82-110$.

Roth K, Schweiger D, Morrison A. Global strategy implementation at the business level: Operational capabilities and administrative mechanism. J Int Bus Stud $1991 ; 22: 369-402$.

Saarenketo S, Puumalainen K, Kuivalainen O, Kylaheiko K. Dynamic knowledge-related learning processes in internationalizing high-tech SMEs. Int J Prod Econ 2004; 89(3):363-378.

Saran A S, Guo C Q. Competing in the global marketplace: The case of India and China. Bus Horiz 2005; 48:135-142.

Segal A. Autonomy, security, and inequality: China, India, the United States, and the globalization of science and technology. Technol Soc 2008; 30:423-428.

Simonen J, McCann P. Firm innovation: The influence of R\&D cooperation and the geography of human capital inputs. J Urban Econ 2008; 64:146-154.

Srholec M. A multilevel analysis of innovation in developing countries. TIK working paper on Innovation Studies 20080812; 2008. 
Tidd J, Bassant J, Pavitt K. Managing innovation: Integrating technology, market, and organizational change. Chichester, UK: Wiley; 1997.

UNCTAD, Transnational corporations and the internationalization of R\&D. World Investment Report 2005, Geneva.

UNCTAD, WIR2009 FDI outflows (WIR - Key Data from Annex of WIR 2009).

Wang C H, Hsu L C, Fang S R. The determinants of internationalization: Evidence from the Taiwan high technology industry. Technol Forecast Soc Change 2008; 75:1388-1395.

Wernerfelt B. A resource-based view of the firm. Strateg Manage J 1984; 5:171-180.

Wilsdon J, Keeley J. China: The next science superpower. London: Demos; 2007.

Zhao W, Watanabe C. A comparison of institutional systems affecting software advancement in China and India: The role of outsourcing from Japan and the United States. Technol Soc 2008; 30:429-436. 